\title{
Context-dependent conservation responses to emerging wildlife diseases
}

Kate E Langwig $^{1 *}$, Jamie Voyles ${ }^{2}$, Mark Q Wilber ${ }^{3}$, Winifred F Frick ${ }^{1}$, Kris A Murray ${ }^{4,5}$, Benjamin M Bolker ${ }^{6}$, James P Collins ${ }^{7}$, Tina L Cheng ${ }^{1}$, Matthew C Fisher ${ }^{8}$, Joseph R Hoyt ${ }^{1}$, Daniel L Lindner ${ }^{9}$, Hamish I McCallum ${ }^{10}$, Robert Puschendorf ${ }^{11}$, Erica Bree Rosenblum ${ }^{12}$, Mary Toothman ${ }^{3}$, Craig KR Willis ${ }^{13}$, Cheryl J Briggs ${ }^{3}$, and A Marm Kilpatrick ${ }^{1}$

Emerging infectious diseases pose an important threat to wildlife. While established protocols exist for combating outbreaks of human and agricultural pathogens, appropriate management actions before, during, and after the invasion of wildlife pathogens have not been developed. We describe stage-specific goals and management actions that minimize disease impacts on wildlife, and the research required to implement them. Before pathogen arrival, reducing the probability of introduction through quarantine and trade restrictions is key because prevention is more cost effective than subsequent responses. On the invasion front, the main goals are limiting pathogen spread and preventing establishment. In locations experiencing an epidemic, management should focus on reducing transmission and disease, and promoting the development of resistance or tolerance. Finally, if pathogen and host populations reach a stable stage, then recovery of host populations in the face of new threats is paramount. Successful management of wildlife disease requires risk-taking, rapid implementation, and an adaptive approach.

Front Ecol Environ 2015; 13(4): 195-202, doi:10.1890/140241

$\mathrm{E}_{\mathrm{t}}^{\mathrm{n}}$ merging infectious diseases can threaten wildlife populations already imperiled by other risks, drive abundant species to rarity or extinction, and alter the structure of entire communities (Van Riper et al. 1986; Skerratt et al. 2007; Langwig et al. 2012). Several potential disease management strategies have been proposed (Wobeser 2002; Woodhams et al. 2011; Joseph et al. 2013) but invasion stageappropriate management actions have not been organized

\section{In a nutshell:}

- Timely, stage-specific management actions are needed to combat emerging infectious diseases of wildlife

- The pathogen invasion process across landscapes can be divided into four distinct stages - Pre-arrival, Invasion front, Epidemic, and Established - that help determine appropriate management actions

- Management actions to be conducted at appropriate stages include quarantine, treatment, culling, captive breeding, facilitation of host resistance, and habitat manipulation

- Effective intervention requires merging research and management actions in an adaptive management framework

- Combating emerging wildlife diseases necessitates attempting interventions with limited information, which entails risktaking; a lack of action frequently results in monitoring species to extinction

${ }^{1}$ Department of Ecology and Evolutionary Biology, University of California, Santa Cruz, Santa Cruz, CA * (klangwig@gmail.com); ${ }^{2}$ Department of Biology, New Mexico Institute of Mining and Technology, Socorro, NM; ${ }^{3}$ Department of Ecology, Evolution and Marine Biology, University of California, Santa Barbara, Santa Barbara, CA; ${ }^{4}$ Grantham Institute - Climate Change and the Environment, Imperial College London, London, UK; continued on p 202 into a cohesive framework, which has largely resulted in haphazard, ineffective, and, in some cases, inappropriate management actions. This, in turn, has led to missed opportunities to reduce disease-related impacts on wildlife populations. Here, we describe stage-specific action plans, to be implemented before, during, and after pathogen invasion, for managing emerging wildlife diseases.

The toolbox of interventions available to manage emerging wildlife diseases includes a wide range of localand broad-scale options (Wobeser 2002; Woodhams et al. 2011). The key question for disease management is which tool will be effective for a disease in a given region at a given time; this depends on the stage of pathogen invasion. Mirroring the frameworks used for invasive species (Blackburn et al. 2011), we divided the pathogen invasion process into four stages - Pre-arrival, Invasion front, Epidemic, and Established - based on differences in disease dynamics and appropriate management actions (Table 1 and Figure 1). Identifying the invasion stage of the pathogen in a region requires data on host abundance and pathogen prevalence, making initial collection of these data a critical part of disease management.

Informed management decisions also depend on data, which are often challenging to obtain when dealing with a rapidly spreading pathogen. The time-course over which management actions must be implemented is often much faster than the pace of most scientific research. However, if interventions are conducted using an experimental approach with proper controls, then even failed actions can provide valuable information for adaptively managing wildlife disease. Managers and researchers therefore need to communicate regularly to design inter- 


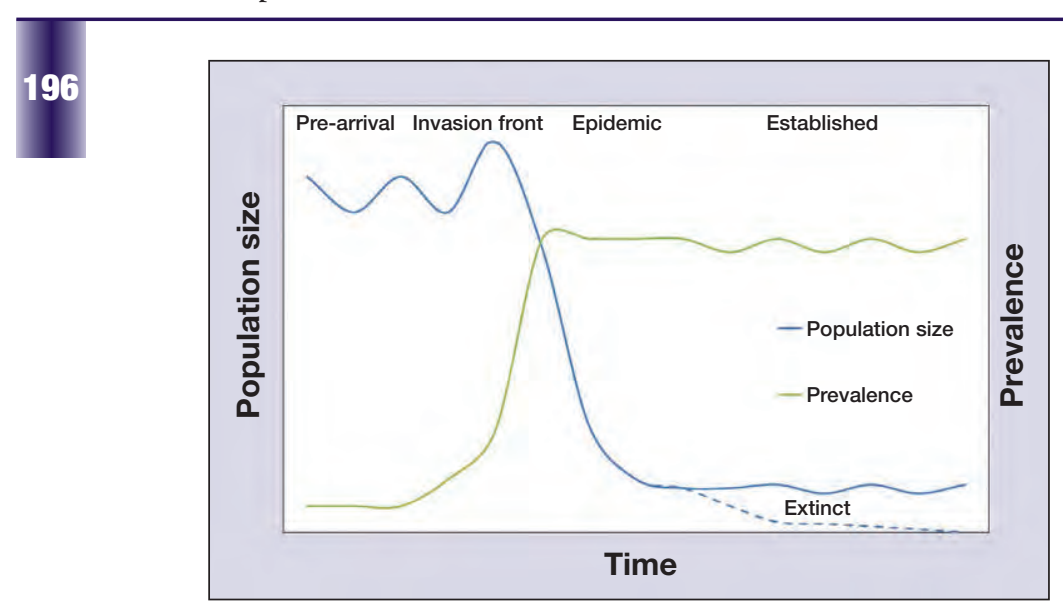

Figure 1. Schematic of host and pathogen dynamics over the course of a pathogen invasion. The four stages at the top of the figure are described in detail in Table 1. If the host population goes extinct (dashed line), then there is no Established stage.

ventions, pool resources, and share findings. Here, we describe goals and effective management actions for each stage of disease emergence (see WebFigure 1).

\section{Pre-arrival}

In Pre-arrival areas the first goal should be to determine whether a disease represents a genuine threat to a region (WebFigure 1), and if so, to prepare for arrival and implement interventions to reduce the probability of introduction. Associated actions may include restricting "risky" commercial trade and other activities, monitoring targeted species, and engaging the public about the impending invasion and their potential role (eg decontamination of gear, hotlines for reporting diseased animals). In addition, although widespread surveillance for pathogens that have yet to be introduced to a remote region is a poor use of resources, it is nonetheless useful to have diagnostic tools ready to identify pathogens in the event of unusual observations of mortality. For example, implementing surveillance on bats in Australia for white-nose syndrome or on wild birds in North America for H5N1 avian influenza

\begin{tabular}{ccc}
\hline Table 1. The four stages of pathogen invasion \\
\hline \begin{tabular}{c} 
Associated characteristics \\
\cline { 2 - 3 } Stage name
\end{tabular} & $\begin{array}{c}\text { Pathogen } \\
\text { prevalence }\end{array}$ & $\begin{array}{c}\text { Host population } \\
\text { trends }\end{array}$ \\
\hline $\begin{array}{c}\text { Pre-arrival } \\
\text { (pathogen arrival is not imminent) }\end{array}$ & Absent & - \\
\hline $\begin{array}{c}\text { Invasion front } \\
\text { (pathogen invasion has just } \\
\text { occurred or is imminent) }\end{array}$ & $\begin{array}{c}\text { Absent or } \\
\text { increasing }\end{array}$ & $\begin{array}{c}\text { Stable or } \\
\text { initial declines }\end{array}$ \\
\hline $\begin{array}{c}\text { Epidemic } \\
\text { (pathogen present) }\end{array}$ & Moderate to high & Declining \\
\hline $\begin{array}{c}\text { Established } \\
\text { (pathogen present) }\end{array}$ & Variable but stable & Stable \\
\hline
\end{tabular}

Notes: "Prevalence is relative and varies among hosts and pathogens. The prevalence descriptions in this column refer to relative prevalence among stages. Dash $=$ not applicable. virus is not especially useful because these pathogens are absent from those respective regions, and the probability of them being introduced and subsequently detected is very low. In contrast, testing animals imported from regions where the pathogen is present would be a more efficient use of resources. Determining the likely pathways of introduction is necessary for targeted testing. Furthermore, taking action during the Pre-arrival stage, or as early in the invasion process as possible, can help to mitigate the costs of interventions that increase as the invasion progresses.

\section{Risk assessment}

Predicting the likelihood of pathogen establishment and disease impact requires an understanding of whether local species would be suitable hosts and whether environmental conditions will promote or allow pathogen existence. This can be accomplished by analyzing phylogenetic and ecological relationships between local species and species affected, as well as climate assessments of habitat suitability for the pathogen (Kilpatrick et al. 2010a; Murray et al. 2011; Martel et al. 2014). Risk assessments that rely on biologically meaningful characteristics of the pathogen or disease, although useful, have rarely been carried out. Most assessments to date have been based solely on easily available climatic datasets, which could be greatly improved upon by integrating a variety of data types.

\section{Restriction of risky products}

In at-risk Pre-arrival areas, preventing introduction should be the primary goal. This requires appropriate levels of targeted biosecurity, and may include quarantining, testing, or restricting the movement of potentially infected animals or products; examples include monitoring amphibians for chytridiomycosis (Kilpatrick et al. 2010a) and poultry for avian influenza viruses (Kilpatrick et al. 2006a). However, because the cost and impact of these measures on trade can be substantial, they must be predicated on a quantitative assessment of the potential pathways of introduction (Kilpatrick et al. 2006b). Only a scientifically backed analysis that identifies the most likely modes of invasion, while concurrently trying to keep restrictions at a minimum, will be palatable to governments and industry.

\section{Public awareness}

Communication between the general public and government agencies responsible for wildlife disease management can facilitate the early detection of invading pathogens. Reports by members of the public were instrumental in leading agencies to recognize the spread of white-nose syndrome, West Nile virus, H5N1 avian influenza, Mycoplasma gallisepticum in house finches, multiple pathogens of frogs (ranaviruses and Batrachochytrium dendrobatidis), and 
raccoon rabies (Hochachka and Dhondt 2000; Marfin et al. 2001; Kilpatrick et al. 2006a; Langwig et al. 2012; Freuling et al. 2013). Improvements in detection are being made by mapping disease outbreaks through non-traditional sources such as web-trawling, but most resources are directed toward detecting human diseases (eg HealthMap, http://healthmap.org). Filtering and directing information from monitoring efforts to appropriate agencies - those that have the resources and skills to investigate unusual morbidity and mortality events potentially caused by disease - remains a challenge (Voyles et al. 2014).

\section{Targeted monitoring}

Population monitoring programs can also contribute to the detection of disease invasion by focusing on species that are cost effective to monitor and that suffer mortality from the invading pathogens. Some species' traits, such as being highly social or mobile, may facilitate rapid pathogen transmission and spread (Bielby et al. 2008). For example, American crows (Corvus brachyrhynchos) - which are social and mobile, occur in urban and residential areas, and experience high mortality from West Nile virus - were key sentinel species for detecting West Nile virus transmission and spread in North America (Marfin et al. 2001).

\section{Invasion front}

In regions where a pathogen has recently arrived or where its arrival is imminent, the goals of management should be to prevent pathogen establishment, slow its spread, and minimize impacts to preserve genetically viable host populations (WebFigure 1). Relevant management actions may include host culling, quarantine, behavioral modification, and prophylactic (ie preventive or protective) treatment. However, some interventions that have been important in controlling human disease, such as contact tracing (ie tracking people with whom an infected individual has had contact; Riley et al. 2003), are frequently not possible with wildlife. Identifying the spatial extent and spreading mechanisms of the pathogen determines which tools will be effective in preventing pathogen expansion. Attempting multiple strategies and learning from both successful and failed efforts will allow for an adaptive approach.

\section{Pathogen eradication}

If an invading pathogen is first detected in a small area on a previously unoccupied continent or region, or on an isolated island, draconian measures (eg widespread chemical application or population culling) should be considered if their implementation would likely eradicate the pathogen and prevent its establishment (Lachish et al. 2010). For instance, an introduced invasive species (the black-striped mussel, Mytilopsis sallei) was successfully eradicated through the use of large quantities of chlorine and copper sulfate in three bays in Australia (Ferguson 2000). Although this intervention had substantial negative short-term effects on the local environment, these were outweighed by its success in preventing establishment of this highly damaging species. Despite few examples of wildlife pathogen eradication, there have been successful efforts at preventing disease establishment, including chronic wasting disease in deer in New York (Jennelle et al. 2014) and rabbit hemorrhagic disease in Mexico (Gregg et al. 1991), as well as several zoonotic diseases such as monkeypox in the US (Bengis et al. 2004).

A key challenge when using culling to eradicate a pathogen (as opposed to reducing host densities to decrease transmission) is identification and removal of all infectious individuals, which is difficult even with effective diagnostic tools (Wobeser 2002; Lachish et al. 2010). Active surveillance for an invading pathogen often focuses on dead or visibly sick animals, but transmission in reservoir hosts often occurs without symptoms (Levinson et al. 2013). Thus, disease may be detected long after pathogen spread from the local area has occurred. In such cases, pathogen eradication will not be feasible and culling will be ineffective, and often counterproductive, in that resistant individuals may be killed (Kilpatrick et al. 2009).

\section{Reducing local spread}

If a pathogen establishes locally, then actions to reduce its spread become paramount. Identifying host factors that may be important in pathogen spread (eg host densities or contact rates) and natural geographical features that impede spread (eg mountains) can help target intervention activities (Smith et al. 2005; Kilpatrick et al. 2006a). However, most documented examples of management actions to reduce disease spread have targeted humans or livestock rather than wildlife. For example, American bison (Bison bison) in Yellowstone National Park are discouraged from leaving park boundaries by hazing (using pyrotechnics, helicopters, and horseback riders), to prevent spillover of brucellosis to nearby cattle (Kilpatrick et al. 2009). Similarly, an electrified fence installed around the perimeter of South Africa's Kruger National Park prevents wildlife from leaving the park's confines and potentially passing bovine tuberculosis to cattle on neighboring farms (Renwick et al. 2007). Nonetheless, approaches aimed at reducing local spread of diseases that affect wildlife could prove to be effective.

\section{Captive assurance and cryobanking}

If a pathogen is spreading rapidly and threatens species with extinction, then forming a captive assurance colony - or cryobanking sperm, eggs, or zygotes to hold genetically sound populations in captivity - may be warranted (Woodhams et al. 2011). However, there are few successful examples of this approach, which carries many challenges. 


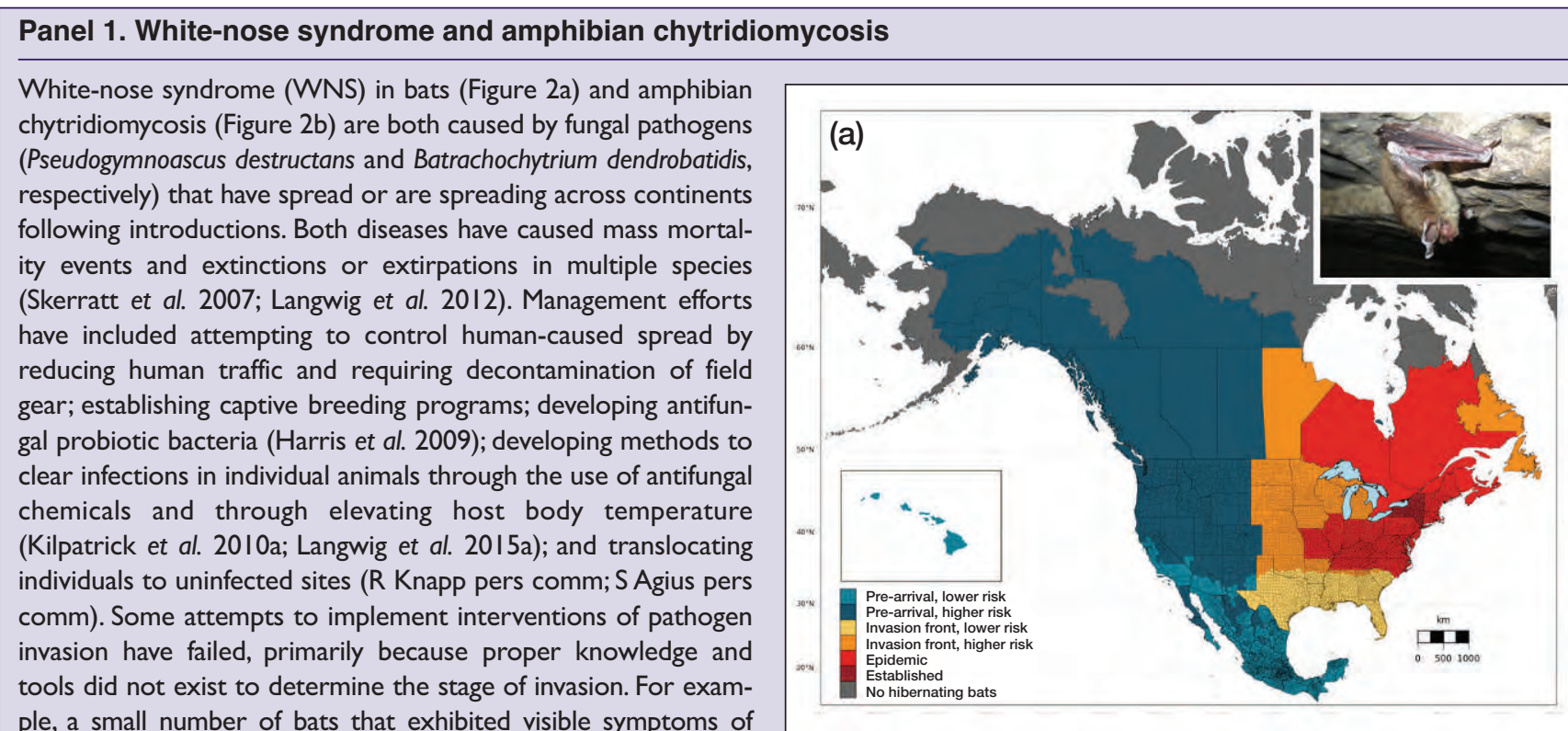
WNS were culled at a site in Kentucky (B Hines pers comm). This was unsuccessful in reducing spread or establishment because the site had already entered the Epidemic phase, and infection was very high in asymptomatic bats; this became clear after development of molecular diagnostic tools (qPCR).

While WNS currently exists in several different stages across North America (Figure 2a), for chytridiomycosis most regions now fall into the Established stage (Figure 2b). Future actions for managing both diseases should include: augmenting host demographic rates by reducing other stressors such as predation, which will also facilitate the evolution of host resistance or tolerance (Kilpatrick 2006); altering site microclimates or biotic communities to reduce transmission and pathogen population growth (Langwig et al. 20I2); and developing methods to decrease pathogen viability in the environment (Langwig et al. 20I5b). Integrating multiple actions and performing interventions in collaboration with researchers will facilitate the use of an adaptive approach and will maximize the probability of success. The high impact of these diseases ( $>90 \%$ declines within a few years in multiple species) and the ecosystem consequences of bat and amphibian declines make interventions necessary and justify taking risks to prevent extinctions.

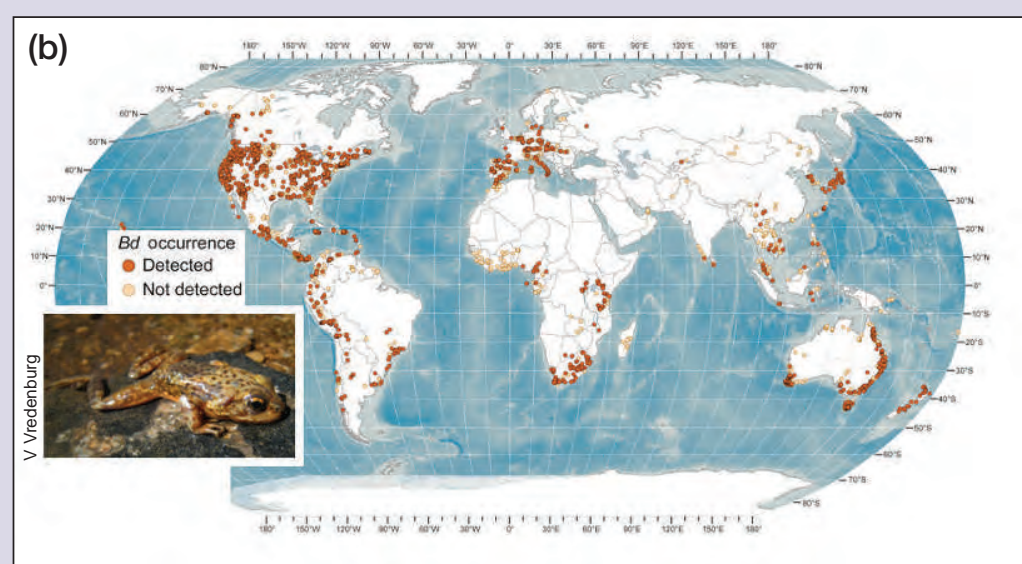

Figure 2. (a) Map of the four stages of invasion for white-nose syndrome, which continues to spread westward from its current distribution (https://www.whitenosesyndrome.org/resources/map). Invasion front and Prearrival regions with long winters (temperatures below $10^{\circ} \mathrm{C}$ for 3 months) are at higher risk, because mortality occurs 70-100 days after infection (Warnecke et al. 2012). The inset shows a northern long-eared bat (Myotis septentrionalis) affected by white-nose syndrome. (b) Map of the global distribution of Batrachochytrium dendrobatidis $(B d)$, which exists on every continent where amphibians occur (www.Bd-maps.net). The inset shows a southern mountain yellow-legged frog (Rana muscosa) affected by chytridiomycosis, the disease caused by Bd.
An attempt to create a colony of Virginia big-eared bats (Corynorhinus townsendii virginianus) to protect the species from white-nose syndrome failed when captive animals died as a result of difficulties with animal husbandry. Similarly the last remaining individuals of the sharpsnouted day frogs (Taudactylus acutirostris) died shortly after capture (Banks et al. 2002). In addition, successful reintroduction requires breeding resistance into captive populations. Despite these complications, establishing captive assurance colonies may be effective in some cases and is currently being pursued to protect some amphibian species from chytridiomycosis (Panel 1).

\section{Epidemic}

Once a pathogen has established within a region, and before pathogen transmission and host populations stabilize, the primary goal of management action should shift from limiting spatial spread to reducing impacts among affected populations (WebFigure 1). This objective can be accomplished either by reducing pathogen transmission (through vaccination or chemical or biological treatments on hosts or habitats), or by augmenting host demographic rates (increasing host birth rates or enhancing survival from non-disease-related mortality). 
The latter, if done properly, could facilitate the evolution of host resistance or tolerance (Kilpatrick 2006).

\section{Vaccination}

If hosts can acquire lasting immunity to a pathogen, vaccination may provide an effective tool for protecting individuals from disease. Successful examples of short-term management of small populations using vaccines include vaccination of California condors (Gymnogyps californianus) against West Nile virus (Chang et al. 2007), Ethiopian and red wolves (Canis simensis and C rufus, respectively) against rabies (Harrenstien et al. 1997; Haydon et al. 2006), and black footed ferrets (Mustela nigripes) against sylvatic plague (Roelle et al. 2006). If vaccination-conferred immunity is life-long, vaccination may require less frequent or intense intervention than chemical treatment to clear hosts of infection, especially if an environmental reservoir or another species may re-infect treated individuals. Yet even for vaccines that confer lasting immunity to individuals, the short lifespans of many wildlife species necessitate repeated and relatively frequent efforts to vaccinate populations and provide herd immunity (Wobeser 2002), emphasizing the importance of an inexpensive yet efficient delivery mechanism (eg aerial bait drops; Smith et al. 2005). In addition to directly vaccinating species of interest, many attempts to control human diseases through vaccination have indirectly benefitted wildlife. Vaccination of wildlife to reduce infections in humans caused by zoonotic pathogens such as rabies and West Nile virus would also benefit wildlife that suffer from these diseases (Kilpatrick et al. 2010b; Freuling et al. 2013).

\section{Treatment with chemical or biological agents}

Chemicals or biological agents (eg probiotic bacteria) have been used in humans and livestock to reduce transmission by clearing infection in individuals, vectors, or the environment, or to reduce disease severity in infected hosts. For instance, mosquito control through insecticides is a cornerstone of vector-borne disease control. More recently, intracellular parasites of the genus Wolbachia have shown promise as a biological agent blocking dengue virus infection in Aedes mosquitoes (Hoffmann et al. 2011). However, cases of successful implementation of public health tools to benefit wildlife are rare (Panel 2). Although probiotic bacteria have been used to reduce disease impacts of chytridiomycosis in amphibians in the laboratory (Harris et al. 2009), successful field trials have yet to be reported. Disease management with drugs (as with vaccination) often requires perpetual implementation to be effective. For example, Arctic foxes (Alopex lagopus) were successfully treated for sarcoptic mange (Mörner 1992), but this required capturing each fox, necessitating continuous funding to ensure the project's longterm success.

\section{Habitat manipulation}

Manipulating abiotic (eg microclimates) and biotic (eg community composition) aspects of the environment can reduce the growth or persistence of pathogens and vectors by taking advantage of natural variation in the suitability of environments for disease (Langwig et al. 2012; Paull et al. 2012). In attempts to control human diseases, many habitatscale manipulations have been carried out, including: draining wetlands to eliminate mosquito habitat for malaria control, clearing wooded areas around residential houses to reduce tick abundance and the risk of Lyme disease, conducting controlled burns to minimize the presence of vectors, and draining standing water to reduce water-borne transmission of avian cholera (Wobeser 2002). Evidence suggests that similar approaches could be effective for wildlife disease. For example, bats roosting at cooler temperatures and lower humidity suffer lower mortality from whitenose syndrome (Panel 2; Langwig et al. 2012); thus, air flow in some hibernacula could be altered to make them cooler or drier, and access to warm humid areas could be restricted. Environmental manipulation is an underappreciated tool for the management of wildlife disease; although logistical problems exist in avoiding unintended consequences, the method is long lasting and has the potential to provide disease-free refuges that could harbor source populations.

\section{Augmenting demographic rates}

Reducing non-disease sources of mortality - such as predation - and augmenting reproduction can sometimes enable populations to persist in the presence of disease. Decreasing predation or competition through the removal of invasive species, or providing predation refuges, are two possible strategies (Vanderwerf and Smith 2002; Pitt et al. 2011). Habitat enhancement that allows easier access to highquality foraging areas could also help to increase fitness (Cohn 1999). Augmenting fitness will be less effective if transmission is density-dependent, since transmission and disease impacts will increase simultaneously and may partially negate the benefits of management actions.

\section{Facilitated evolution of host resistance or tolerance}

Even if transmission increases with increasing host density, augmenting demographic rates (ie survival and reproduction) will facilitate the evolution of host resistance or tolerance if heritable variation for these traits exists in a population. Reducing stressors other than the focal disease allows populations to evolve more quickly because they can persist with higher selective pressures from disease (Kilpatrick 2006; McCallum 2012). Decreasing rodent predator abundance (rats) was predicted to enable much faster evolution of tolerance to avian malaria in Hawaiian birds (Kilpatrick 2006). Unfortunately, no genetically based resistance or tolerance has yet been identified for several recently emerged diseases, including white-nose 


\section{Panel 2. Lessons learned from human and livestock disease control}

Many human or agricultural pathogens have recently been introduced or pose threats to new regions; the successful control of those diseases provides insight for managing infectious diseases of wildlife. Trade restrictions have helped reduce the probability of introduction of several human and agricultural pathogens. For example, after an outbreak of monkeypox in the US was traced to the sale of Gambian pouched rats (Cricetomys gambianus), restrictions were put in place that prevented trade of these animals from this region (Bengis et al. 2004). Restrictions on the selling of bullfrogs could benefit wildlife by reducing the probability of spread of the amphibian pathogen $B$ dendrobatidis into new regions, such as Madagascar, which remains unaffected (Figure $2 b$; Kilpatrick et al. 20I0a).Travel restrictions on humans have also helped reduce the spread of human (eg Ebola and SARS; Riley et al.2003) and agricultural (eg Brucellosis and highly pathogenic avian influenza; Kilpatrick et al. 2006a; Kilpatrick et al. 2009) pathogens between countries and continents. International travelers arriving into the US are screened by customs officials to determine whether they have visited a farm, which helps to prevent the introduction of foot and mouth disease. Screening travelers to identify those that have visited caves or mines could similarly reduce accidental spread of the fungus causing white-nose syndrome from areas where it is present.

Once human pathogens have reached the Established stage, efforts to reduce spatial spread are abandoned and focus shifts to reducing the transmission and severity of disease. One way of reducing transmission of food- and water-borne pathogens such as cholera, Escherichia coli, leptospirosis, and typhoid is through improved sanitation (Ashbolt 2004). For wildlife, improved sanitation of terrestrial environments may reduce transmission of terrestrial pathogens to marine ecosystems (Figure 3). Sea otters foraging near human-dominated coastlines are at higher risk of infection with two pathogens - Toxoplasma gondii and Sarcocystis
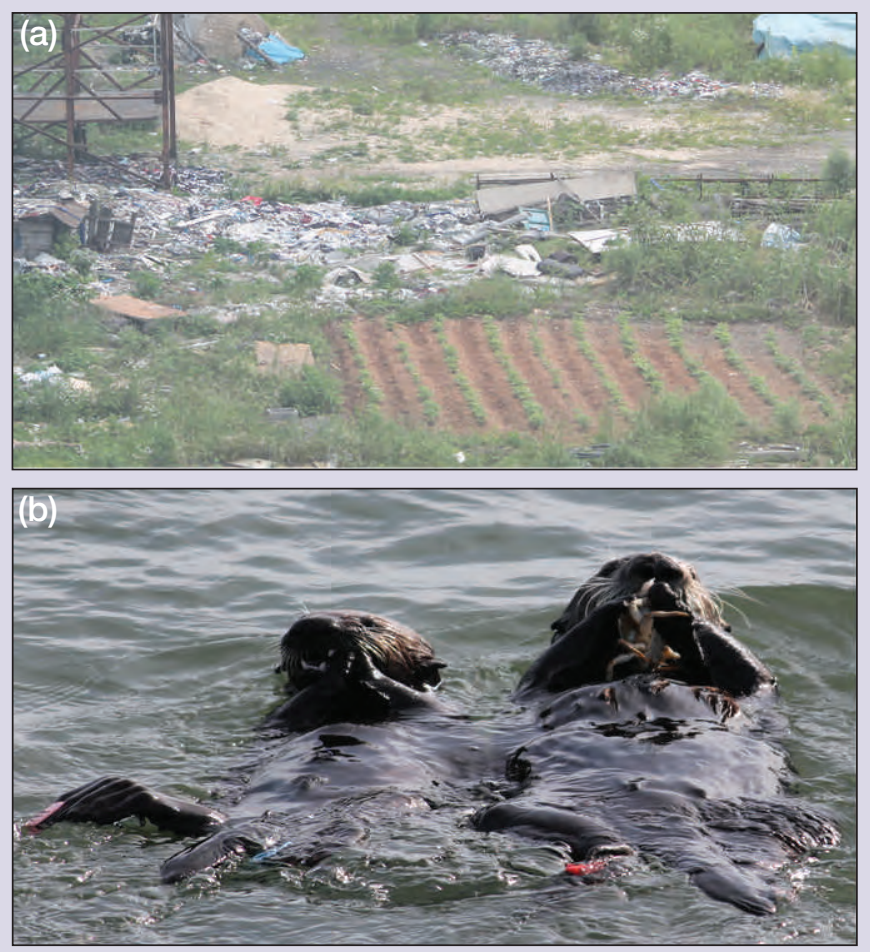

Figure 3. (a) Vegetables grown next to heaps of waste in a city in Liaoning province, China. Improved sanitation can reduce risk of intestinal infection due to contaminated food and water. (b) Sea otters (Enhydra lutris) forage near the shoreline in Monterey Bay, CA. Otters closer to human-occupied coastlines have higher infection prevalence of Toxoplasma gondii and Sarcocystis neurona. neurona, both shed by human commensal species (cats and opossums, respectively) - than those foraging on higher quality prey items that may be present in higher abundance in areas farther from human development (Johnson et al. 2009). Managing human and wildlife disease requires an adaptive approach that addresses the unique attributes of each group of hosts and pathogens.

syndrome and chytridiomycosis. Determining whether natural resistance or tolerance occurs is an important research priority for managing these diseases. This is because the evolution of tolerance in one species may increase pathogen transmission to - and lead to greater impacts on - other host species or populations.

\section{Host translocation}

If genetically resistant individuals or subpopulations exist, translocation of these individuals to facilitate the spread of resistant alleles is an important conservation strategy (Kilpatrick 2006). For instance, genetic variability in susceptibility to Tasmanian devil facial tumor disease appears to exist in Tasmanian devils, and may underlie differences in disease impacts among populations (Hamede et al. 2012). Translocation of resistant devils to areas where numbers have been greatly reduced could help restore these populations. In general, if resistant populations can be identified in the wild, then transloca- tions to suitable habitat would be preferable to the cost and difficulties of maintaining captive populations.

\section{Established}

If disease dynamics stabilize and populations have not been locally extirpated, management should aim to protect and restore persisting populations and, if necessary, manage ecosystems to account for the impacts of the pathogen (WebFigure 1). Remaining host populations may exist in refuges that are unsuitable for growth, persistence, or invasion of the pathogen (Langwig et al. 2012), and protecting these areas from disturbance or predators should be a high priority (Murray et al. 2011). In addition, actions that are appropriate at the Epidemic stage (eg translocation to promote genetic diversity of remnant populations, treatment, vaccination, facilitated evolution, and habitat manipulation) should also be considered. However, the risks associated with carrying them out should be weighed more heavily against the potential benefits during the Established stage. 


\section{Additional threats}

Once the Established stage has been reached, new stressors - including changes in climate and land use, and new species invasions - put additional pressure on populations struggling to persist. These changes have the potential to alter the population and pathogen trajectories that again put species at risk of extinction. The best strategies to address this ongoing challenge are to facilitate the evolution of resistance and tolerance, decrease mortality and pathogen transmission, and augment disease-independent population growth rates, so that species can survive both current and impending threats. This approach preserves the evolutionary potential of populations by restoring them to a level such that they possess ample genetic and phenotypic variability (Forest et al. 2007).

Successful implementation of the actions outlined above requires research, long-term management, and sufficient funding to establish the necessary management and scientific infrastructure (Voyles et al. 2014). For example, disease reduction through treatment, habitat manipulation, or vaccination is more efficient when pathogen transmission dynamics and disease pathology are well understood. Research enables transmission reduction strategies to be directed toward the most important reservoir hosts or locations (Kilpatrick 2011; Paull et al. 2012). Combining empirical observational and experimental studies with statistical and mechanistic models is usually the most efficient way to determine the key factors driving transmission and disease dynamics.

\section{Conclusions}

Disease has driven wildlife species and populations to extinction and extirpation, irretrievably altering community compositions. For many species threatened by invading pathogens, few interventions have been attempted, or interventions have been implemented too late. In many cases, managers have "let nature take its course" and species have been monitored to extinction. Numerous wildlife pathogen introductions have clearly occurred through human trade and travel; the subsequent impacts of these ecosystem-level perturbations - similar to those associated with habitat destruction and degradation, such as oil spill events - should be mitigated or eliminated. The stage-specific framework we have outlined should be used to address this need and better manage the impacts of emerging pathogens on wildlife.

In addition to implementing stage-specific interventions, four additional aspects play a major role in the success or failure of management. First, all management actions - successful or otherwise - entail risk; to implement the interventions, managers need to be willing to assume substantial risk. Although such risks should be weighed against their potential benefits, they should also be compared to the likely (often negative) outcomes associated with inaction. Second, developing a management plan and timeline for actions prior to, or as soon as possible after, pathogen arrival is crucial because early action is considerably more cost effective than the same approach taken later (McCallum and Jones 2006). Third, the public must be engaged through all possible avenues to aid in reducing pathogen spread, promote decontamination, and offer financial support for management and research activities. Fourth, management should be adaptive and the efficacy of different strategies should be assessed concurrently with implementation to inform future management policies. This approach entails sharing knowledge between academics and managers as soon as data can be analyzed and before the extended delays often associated with publication. Only through collaboration among managers, scientists, and the public can the challenge of emerging wildlife diseases be effectively met.

\section{Acknowledgements}

Ideas for this paper were developed during the National Center for Ecological Analysis and Synthesis working group "Fungal pathogens and disease-induced extinction: are fungal diseases different?". Funding was provided by the US National Science Foundation (grants EF-0914866, DGE-0741448, DEB-1115069, DEB-1336290) and the National Institutes of Health (grant 1R010AI090159).

\section{References}

Ashbolt NJ. 2004. Microbial contamination of drinking water and disease outcomes in developing regions. Toxicology 198: 229-38.

Banks C, McCracken H, and Natrass A. 2002. Captive management and pathology of sharp snouted day frogs, Taudactylus acutirostris, at Melbourne and Taronga zoos. Frogs in the community: Proceedings of the Brisbane Symposium; 13-14 Feb 1999; East Brisbane, Australia. East Brisbane, Australia: Queensland Frog Society.

Bengis RH, Leighton FA, Fischer JR, et al. 2004. The role of wildlife in emerging and re-emerging zoonoses. Rev Sci Tech OIE 23: 497-511.

Bielby J, Cooper N, Cunningham AA, et al. 2008. Predicting susceptibility to future declines in the world's frogs. Conserv Lett 1 : 82-90.

Blackburn TM, Pyšek P, Bacher S, et al. 2011. A proposed unified framework for biological invasions. Trends Ecol Evol 26: 333-39.

Chang GJJ, Davis BS, Stringfield C, et al. 2007. Prospective immunization of the endangered California condors (Gymnogyps californianus) protects this species from lethal West Nile virus infection. Vaccine 25: 2325-30.

Cohn JP. 1999. Saving the California condor - years of effort are paying off in renewed hope for the species' survival. BioScience 49: 864-68.

Ferguson R. 2000. The effectiveness of Australia's response to the black striped mussel incursion in Darwin, Australia. Canberra, Australia: Community Information Unit, Department of Environment and Heritage.

Forest F, Grenyer R, Rouget M, et al. 2007. Preserving the evolutionary potential of floras in biodiversity hotspots. Nature 445 : $757-60$.

Freuling CM, Hampson K, Selhorst T, et al. 2013. The elimination of fox rabies from Europe: determinants of success and lessons for the future. Philos T R Soc B 368: 20120142.

Gregg DA, House C, Meyer R, et al. 1991. Viral haemorrhagic dis- 
ease of rabbits in Mexico: epidemiology and viral characterization. Rev Sci Tech OIE 10: 435-51.

Hamede R, Lachish S, Belov K, et al. 2012. Reduced effect of Tasmanian devil facial tumor disease at the disease front. Conserv Biol 26: 124-34.

Harrenstien LA, Munson L, Ramsay EC, et al. 1997. Antibody responses of red wolves to canine distemper virus and canine parvovirus vaccination. J Wildlife Dis 33: 600-05.

Harris RN, Brucker RM, Walke JB, et al. 2009. Skin microbes on frogs prevent morbidity and mortality caused by a lethal skin fungus. ISME J 3: 818-24.

Haydon DT, Randall DA, Matthews L, et al. 2006. Low-coverage vaccination strategies for the conservation of endangered species. Nature 443: 692-95.

Hochachka WM and Dhondt AA. 2000. Density-dependent decline of host abundance resulting from a new infectious disease. P Natl Acad Sci USA 97: 5303-06.

Hoffmann AA, Montgomery BL, Popovici J, et al. 2011. Successful establishment of Wolbachia in Aedes populations to suppress dengue transmission. Nature 476: 454-57.

Jennelle CS, Henaux V, Wasserberg G, et al. 2014. Transmission of chronic wasting disease in Wisconsin white-tailed deer: implications for disease spread and management. PLoS ONE 9: e91043.

Johnson CK, Tinker MT, Estes JA, et al. 2009. Prey choice and habitat use drive sea otter pathogen exposure in a resource-limited coastal system. P Natl Acad Sci USA 106: 2242-47.

Joseph MB, Mihaljevic JR, Arellano AL, et al. 2013. Taming wildlife disease: bridging the gap between science and management. J Appl Ecol 50: 702-12.

Kilpatrick AM. 2006. Facilitating the evolution of resistance to avian malaria in Hawaiian birds. Biol Conserv 128: 475-85.

Kilpatrick AM. 2011. Globalization, land use, and the invasion of West Nile virus. Science 334: 323-27.

Kilpatrick AM, Briggs CJ, and Daszak P. 2010a. The ecology and impact of chytridiomycosis, an emerging disease of amphibians. Trends Ecol Evol 25: 109-18.

Kilpatrick AM, Chmura AA, Gibbons DW, et al. 2006a. Predicting the global spread of H5N1 avian influenza. P Natl Acad Sci USA 103: 19368-73.

Kilpatrick AM, Daszak P, Goodman SJ, et al. 2006b. Predicting pathogen introduction: West Nile virus spread to Galapagos. Conserv Biol 20: 1224-31.

Kilpatrick AM, Dupuis AP, Chang GJ, and Kramer LD. 2010b. DNA vaccination of American robins (Turdus migratorius) against West Nile virus. Vector-Borne Zoonot 10: 377-80.

Kilpatrick AM, Gillin CM, and Daszak P. 2009. Wildlife-livestock conflict: the risk of pathogen transmission from bison to cattle outside Yellowstone National Park. J Appl Ecol 46: 476-85.

Lachish S, McCallum H, Mann D, et al. 2010. Evaluation of selective culling of infected individuals to control Tasmanian devil facial tumor disease. Conserv Biol 24: 841-51.

Langwig KE, Frick WF, Bried JT, et al. 2012. Sociality, densitydependence and microclimates determine the persistence of populations suffering from a novel fungal disease, white-nose syndrome. Ecol Lett 15: 1050-57.

Langwig KE, Frick WF, Reynolds R, et al. 2015a. Host and pathogen ecology drive the seasonal dynamics of a fungal disease, white-nose syndrome. Proc Roy Soc B 282; doi: 10.1098/rspb.2014.2335.

Langwig KE, Hoyt JR, Parise KL, et al. 2015b. Invasion dynamics of white-nose syndrome fungus, Midwestern United States, 2012-2014. Emerg Infect Dis 21; doi:10.3201/eid2106.150123.

Levinson J, Bogich TL, Olival KJ, et al. 2013. Targeting surveillance for zoonotic virus discovery. Emerg Infect Dis 19: 743-47.

Marfin AA, Petersen LR, Eidson M, et al. 2001. Widespread West Nile virus activity, eastern United States, 2000. Emerg Infect Dis 7: 730-35.

Martel A, Blooi M, Adriaensen C, et al. 2014. Recent introduction of a chytrid fungus endangers western Palearctic salamanders. Science 346: 630-31.

McCallum H. 2012. Disease and the dynamics of extinction. Philos T R Soc B 367: 2828-39.

McCallum H and Jones M. 2006. To lose both would look like carelessness: Tasmanian devil facial tumour disease. PLoS Biol 4: $1671-74$.

Mörner T. 1992. Sarcoptic mange in Swedish wildlife. Rev Sci Tech OIE 11: 1115-21.

Murray KA, Retallick RWR, Puschendorf R, et al. 2011. Assessing spatial patterns of disease risk to biodiversity: implications for the management of the amphibian pathogen, Batrachochytrium dendrobatidis. J Appl Ecol 48: 163-73.

Paull SH, Song S, McClure KM, et al. 2012. From superspreaders to disease hotspots: linking transmission across hosts and space. Front Ecol Environ 10: 75-82.

Pitt WC, Driscoll LC, and VanderWerf EA. 2011. A rat-resistant artificial nest box for cavity-nesting birds. Human-Wildlife Interact 5: 100-05.

Renwick AR, White PCL, and Bengis RG. 2007. Bovine tuberculosis in southern African wildlife: a multi-species host-pathogen system. Epidemiol Infect 135: 529-40.

Riley S, Fraser C, Donnelly CA, et al. 2003. Transmission dynamics of the etiological agent of SARS in Hong Kong: impact of public health interventions. Science 300: 1961-66.

Roelle JE, Miller BJ, Godbey JL, and Biggins DE. 2006. Recovery of the black-footed ferret - progress and continuing challenges. Reston, VA: US Geological Survey. Scientific Investigations Report 2005-5293.

Skerratt LF, Berger L, Speare R, et al. 2007. Spread of chytridiomycosis has caused the rapid global decline and extinction of frogs. EcoHealth 4: 125-34.

Smith DL, Waller LA, Russell CA, et al. 2005. Assessing the role of long-distance translocation and spatial heterogeneity in the raccoon rabies epidemic in Connecticut. Prev Vet Med 71: 225-40.

Van Riper C III, Van Riper SG, Goff ML, et al. 1986. The epizootiology and ecological significance of malaria in Hawaiian (USA) land birds. Ecol Monogr 56: 327-44.

Vanderwerf EA and Smith DG. 2002. Effects of alien rodent control on demography of the O'ahu 'Elepaio, an endangered Hawaiian forest bird. Pac Conserv Biol 8: 73-81.

Voyles J, Kilpatrick AM, Collins JP, et al. 2014. Moving beyond too little, too late: managing emerging infectious diseases in wild populations requires international policy and partnerships. EcoHealth; doi:10.1007/s10393-014-0980-5.

Warnecke L, Turner JM, Bollinger TK, et al. 2012. Inoculation of bats with European Geomyces destructans supports the novel pathogen hypothesis for the origin of white-nose syndrome. $P$ Natl Acad Sci USA 109: 6999-03.

Wobeser G. 2002. Disease management strategies for wildlife. Rev Sci Tech OIE 21: 159-78.

Woodhams DC, Bosch J, Briggs CJ, et al. 2011. Mitigating amphibian disease: strategies to maintain wild populations and control chytridiomycosis. Front Zool 8: 8 .

${ }^{5}$ EcoHealth Alliance, New York, NY; ${ }^{6}$ Departments of Mathematics E3 Statistics and Biology, McMaster University, Hamilton, Canada; ${ }^{7}$ School of Life Sciences, Arizona State University, Tempe, AZ; ${ }^{8}$ Department of Infectious Disease Epidemiology, Imperial College London, London, UK; ${ }^{9}$ US Forest Service, Center for Mycology Research, Madison, WI; ${ }^{10}$ School of Environment, Griffith University, Nathan, Australia; "11School of Biological Sciences, Plymouth University, Plymouth, UK; ${ }^{12}$ Department of Environmental Science, Policy and Management, University of California, Berkeley, Berkeley, CA; ${ }^{13}$ Department of Biology, University of Winnipeg, Winnipeg, Canada 